\title{
THE ACTUALIZATION OF LIBERAL INDONESIAN MULTICULTURAL THOUGHT IN DEVELOPING COMMUNITY HARMONIZATION
}

\author{
Ngainun Naim \\ Universitas Islam Negeri Sayyid Ali Rahmatullah Tulungagung \\ naimmas22@gmail.com \\ Mujamil Qomar \\ Universitas Islam Negeri Sayyid Ali Rahmatullah Tulungagung \\ mujamil65@yahoo.com
}

\begin{abstract}
Not many Kiai have thoughts about multiculturalism. Kiai M. Sholeh Bahruddin and Kiai Abdullah Syam are considered unique because they have multicultural Islamic thoughts and actualize them in building community harmony. This paper aimed to explore the basis, approach, and channel of Islamic actualization in responding to various challenges. The research method used was the qualitative method with a symbolic interaction approach. The data collection procedures were conducted through in-depth interviews, observation, and documentation. The data were analyzed by following the steps suggested by Saldana, Miles, and Huberman (2013). This study found that the basis for the actualization of multicultural Islamic thoughts of Kiai M. Sholeh Bahruddin and Kiai Abdullah Syam was social, humanistic, cultural, religious, and psychological. The approach used was a synergy between religious, moral, psychological, theological, cultural, social, and educational
\end{abstract}


approaches. Meanwhile, the actualization channels used are through social channels, cultural arts, propaganda, social media, silaturrahim (hospitality in Islam), education levels, and scientific meetings.

Keywords: Islamic thought, multiculturalism, harmonization, Kiai.

\section{A. Introduction}

Indonesia is a country with a high level of multiculturalism. This is supported by the fact that Indonesia has more than 13,000 islands, 300 tribes, more than 200 different languages, very diverse traditions and cultures, and a lot of religions and beliefs (Miftah, 2016). The high level of multiculturalism is a challenge because the awareness of diversity has not significantly flourished in Indonesia (Raihani, 2014).

Multiculturalism in Indonesia is an interesting aspect because it is related to various aspects of life. Studies on multiculturalism generally discuss from particular perspectives, for example, education (Amirin, 2013; Ansor, 2016; Noorhayati, 2017; Widiastuti, 2018), pesantren or Islamic boarding school (Lubis et al., 2009; Widiastuti, 2018), culture (Dasrun et al., 2017; Wakano, 2019), daqwa or preaching (Rosidi, 2017; Saifulah, 2014), and the paradigm of ușul fiqh (Dahlan, 2012). Various studies on multiculturalism showed that the issue of identity recognition, cultural diversity, and cultural differentiation become pressing challenges that must be addressed (Kymlicka, 2011).

In spite of the substantial number of studies on multiculturalism, until now, there has been no study that 
specifically scrutinized the Islamic multicultural thought of Kiai in building community harmony. Therefore, this study aimed to complement previous multicultural studies. The study of multiculturalism in Islamic boarding schools has indeed been carried out by several scholars (Aly, 2015; Cahyono, 2017; Kuswandi, 2014; Rif' atul et al., 2015). However, these studies are still too general, by which there is a dearth of studies exploring the actualization of multicultural Islamic thought in building community harmony.

This paper was raised from the argument that Kiai is considered a prominent figure in Islamic society (Fauzi, 2012). The thoughts possessed and actions taken by Kiai have broad implications on people's lives. The discussion on the actualization of the multicultural Islamic thought of Kiai M. Sholeh Bahruddin from Ngalah Islamic Boarding School in Pasuruan and Kiai Abdullah Syam from Al-Amin Community Islamic Boarding School in Malang was an effort to discover the construction of multicultural Islamic thought of the two Kiais. The focus of this article covered the rationale, approach, and channels for the actualization of multicultural Islamic thought in building community harmony.

\section{B. Religion, Multicultural, and Community Harmonization}

There are several important concepts related to issues of cultural differences, namely ethnicity and race, culture and society, and religion (Raihani, 2014). Although they have different meanings, the three concepts have mutually reinforcing relationships and interactions. Ethnicity refers to a social group with a specific meaning and position in society, while race is a group with physical characteristics or national 
groups. Culture is the result of human creativity, taste, intention, and work, while society is a collection of people who are bound by the culture they follow. Culture has a very close relationship with the community, while the concept of religion is a belief system that raises several obligations and prohibitions that have to be obeyed by its followers (Raihani, 2014).

Multiculturalism becomes an alternative in exploring the identity of a community not only from its religious background but also from its cultural background (Misrawi, 2012). Thus, culture becomes the center of attention for multiculturalism, by which it is studied, cared for, valued, fought for, preserved, and developed as a treasured nation's wealth.

Multiculturalism has become more robust in recent times for several reasons. First of all, it is due to the openness of society with cultural wealth, capital, and historical experience. Second, the number of religious education institutions that make the face of the education world are considered more dynamic. Third, a rapidly developing industry in various regions across Indonesia has implications for the increasingly diverse cultural backgrounds. Fourth, graduates from various educational institutions have significant roles in various fields. Fifth, more regions in Indonesia have a high level of plurality (Sulalah, 2012).

Religious diversity is not a major concentration for multiculturalism. Instead, it is more on aspects of cultural expression when multiculturalism touches the religious diversity. The reason is that in religious life, the community always raises cultural expression on its adherents. Religious practice cannot be separated from the culture of the people who practice the religion. 
Sociologists concluded that, socially, religion has two sides. On the one hand, religion fosters harmony and peace, social integrity, meaning, and morality. On the other hand, religion also creates wars and revolutions (Yunanto \& Hamid, 2013). In the interrelated framework, people of various beliefs live together to contribute positively to a harmonious community life but never compromise religious belief in the name of multiculturalism (Raihani, 2014). Good social relations will usually form mutually beneficial cooperation in both economic and business aspects, social activities such as community service, cooperation, even in the field of sports. This beneficial cooperation can be nurtured regardless of belief and religion.

Referring to the history of Islam, the concept of multiculturalism has been built since the Medina government led by the Prophet Muhammad. The government system built by the Prophet was rooted in the concept of "al-mujtama' almadani" which led to a value system that was linked to the tradition of "al-hanifiyyah al-samhah" as the goal of siyasah syar'iyyah which laid the foundations of Islamic politics as a universal treatise (Abduh, 2014). The government led by the Prophet as a whole turned out to be not only related to theology, rituals, and ethics but also covered all aspects of human life and life. Islam covers all aspects of culture. Apart from religious principles, there are also philosophical, scientific, and technological principles, including social, economic, legal, and political aspects (Syam, 2015). The government of the Medina era has become a religious pioneer and fostered cooperation between the government and the community, and guaranteed religious freedom by providing 
opportunities for the community to establish local, regional, or even international relations.

The intense awareness of cultural differences fosters an open and respectful attitude towards other cultures as long as they do not disturb the public interest (Baharun \& Awwaliyah, 2017). In this context, multiculturalism is the right choice as a public policy to manage the diversity of Indonesian society. It emphasizes mutual respect and tolerance for cultural diversity, ethnicity, religion, race, customs, and cultural arts (Putranto, 2016).

Indonesia is one of the centers of a democratic and pluralistic Islamic movement. As the majority religion, Indonesian Islam is quite capable of maintaining dialogue with local cultural elements throughout its history (Azra, 2013). This ability is obtained from the historical experience of the existence of Islam in Indonesia itself, namely through a cultural approach. Islamic preaching in Indonesia is carried out by peaceful means through cultural channels. The implication is that Indonesian Islam has a cultural character that is perceived in many religious activities with a local cultural style. Therefore, Indonesian Islam has become accustomed to dealing with the local culture.

This cultural approach has consequential effects on the style of Indonesian Islamic thought, in which the average Indonesian Islamic thought has a moderate pattern. If there are Indonesians who have radical thoughts, they are more likely to be influenced by Islamic ideas from the Middle East. In contrast, a pure influence of Indonesian Islamic thought will not develop a fundamental or radical thought. The underlying reason for this is due to the moderate nature/understanding 
of the Indonesian people (Umar, 2016). This understanding means that from generation to generation, the ancestors of the Indonesian nation have represented diversity successfully without any friction between communities. As a result, the current multicultural concept has been practiced long before the Indonesian nation was established.

Bhineka Tunggal I $k a$ refers to the identity of multiculturalism in Indonesia (Lestari, 2015). This 'Unity in Diversity' motto during the New Order regime has been translated into 'Unity above difference' (Raihani, 2014). Parallel with this translation is agreed in disagreement (Ismail, 2012). After all, Bhineka Tunggal Ika is relatively acceptable to all Indonesian people (Amalia, 2014).

The concept and implementation of multiculturalism have not been thoroughly realized by the Indonesian people. Regarding this, the level of their understanding of multiculturalism is very diverse. Each individual has different circumstances, characters, and belief systems that have not yet been entirely accepted by their collective reasoning. Their collective reasoning about multicultural co-opted logocentrism, hegemonic interpretations are full of prejudice, suspicion, hatred, and reduction of groups outside themselves (Tanudirjo, 2011).

The practical application of the multiculturalism concept in Indonesia from the past has illustrated the application of fundamental principles, such as democracy, humanism, and pluralism or inclusive religious values. Multiculturalism is regarded as more related to a person's level of religiosity. Religiosity means that a person is more aware of his choices in choosing a belief, by which the worship of God is not 
something that is forced (Mailasari, 2016). Religiosity will be reflected in the form of action. In this case, good deeds and tolerance are the aspects needed in a multicultural society.

On the other hand, there are multicultural forms that are interpreted as a part of liberation. Sociological facts reveal that the diversity of Indonesia has been originated long before the Indonesian nation was formed, which means that, historically, the Indonesian people have been accustomed to diversity. However, in the context of the modern Indonesian nation-state, diversity has socio-political meanings and demands that are contrastingly different from the diversity realized by the founders of the Indonesian nation. However, some problems are faced, including the understanding of culture that remains unchanged and the claim of universality of values in various understandings of multiculturalism to address the issues of cultural differences based on the liberalism principles (Dulmanan, 2020).

Indonesia has the intelligence of local culture (local cultural geniuses) as a force that can integrate the lives of multiplecommunities(Lestari,2015).Thismeansthatdiversity has been extensively realized and implemented diversity with democratic values and tolerance in Indonesia for an extended period. For centuries, Indonesia has experienced creating a harmonious life among its communities despite its plural and multicultural conditions (Lestari, 2015). This experience has been accomplished on an ongoing basis long before the emergence of pluralism and multiculturalism discourses. This experience can be reasonably regarded as potential evidence that Indonesia can manage a diverse society in many fields, including religion. 


\section{The Foundation of Multicultural Islamic Thought Actualization}

Multicultural Islamic thought refers to a thought based on Islamic values that respect the cultural diversity that develops in society, including those of minority or non-Islamic cultures. Kiai M. Sholeh Bahruddin, as the caretaker of Ngalah Islamic Boarding School Pasuruan, and Kiai Abdullah Syam as the caretaker of Al-Amin Community Islamic Boarding School Sumberpucung Malang, are two Kiais who have multicultural Islamic thought. Both Kiais greatly appreciate the diversity of local religion and culture. This attitude of honor and respect has a considerable role in unifying multicultural society (Pranowo, 2009).

Kiai M. Sholeh Bahruddin inherited religious and cultural models and life patterns from his ancestors, particularly his father (Kiai Bahruddin) and his grandfather. Both of them are murshid tharîqah, who have flexible views on the issues of social and cultural relations between Muslims and people from other religions. Regarding this, both of them connected a wide variety of relationships across religions, tribes, and ethnicities in the form of very close relationships. The model and pattern of the religious life had been inherited by Kiai M. Sholeh Bahruddin to form an attitude that is open to the culture of minority groups (Pengasuh Pesantren Ngalah Pasuruan, 2019). This legacy alleviates the psychological burden of Kiai M. Sholeh Bahruddin in the presence of Muslims, especially those who oppose it. On the other hand, Kiai Abdullah Syam had no inheritance of inclusive views from his family at all. However, he had experienced living in a pluralistic area and society where he was once part of a marginal society. 
His educational background as a psychology graduate in communication from UIN Maliki Malang and his thesis on Bung Karno also helped shape views and opened attitudes towards the culture of minority groups (Syam, 2019).

In approaching the culture of a minority group, the two Kiais put forward humanitarian motives. Humanity is a fundamental aspect that determines human relations (Madjid, 2003). This motive becomes ammunition to their personality, so despite both are perceived as strange, suspected, complained, openly protested, made fun of, seen as lost and slandered, their determination and attitude in approaching the culture of minority groups cannot be discouraged.

As Kiais, both of them consider Islam a foothold in thinking and acting. The Islamic values recognized by the two Kiais is the one that emphasizes the function as a protector of life that embraces all groups, including minorities, to live in harmony. The religion brought by the Prophet Muhammad is a religion with a set of instructions in dealing with differences that occur in society on cultural differences, religion, ethnicity, nation, language, and other aspects. These instructions teach Muslims to be open to differences, be tolerant, respectful, and appreciative towards the minorities as long as they are not hostile (Yakin, 2016).

For Syam (2019), religion is considered broad and flexible. Meanwhile, according to Kiai Sholeh, religion is not culture, and culture is also not religion. Regarding this, religion and culture have a strong relationship, in which a good culture contains the elements of religious values (Pengasuh Pesantren Ngalah Pasuruan, 2019). The perspectives of both Kiai Abdullah Syam and Kiai M. Sholeh Bahruddin are in 
line with the embedded reality of Islam in various aspects of life. The culture of various ethnic groups and Indonesian nations makes the reality of Muslim culture more adaptive, flexible, and accommodating to provide plenty of room for movements in cultural and political behavior. In addition, Islam Wasathiyah is the dominant paradigm and praxis of Indonesian Islam, making Islam in this country far from Islamist political tendencies (Burhani, 2012; Mu'min \& Mufid, 2018; Mubarak, 2013). Islam Wasathiyah is regarded as a moderate understanding that calls for a tolerant Islamic da'wah instead of all forms of liberal and radical thought. The liberal sense of understanding Islam refers to the lustful standards and pure logic that tends to seek unscientific justifications (Nur \& Mukhlis, 2015). This definition summarizes the overall understanding based on the scholars. Al-Asfahaniy (2009, p. 869) defines "sawa'un" as the middle between two limits, or the standard of the ordinary. Meanwhile, Ibn' Assyria interpreted wasath as something in the middle of something with two ends of the same size. Consequently, the notion of wasath refers to Islamic values that are built based on a straight and middle mindset, not excessive in certain respects ('Âsyûr, 1984).

The hope of Kiai M. Sholeh Bahruddin and Kiai Abdullah Syam was to present calm and comfort for both Muslims and other people. In this case, community life can be harmonious, peaceful, and helpful from one to another. Therefore, the critical key is to find a meeting point instead of a point of difference (Kunawi, 2012).

The existence of a combination of complementary characters is the main reason for this research. 
Multiculturalism education is taught by religious leaders directly. The current measures have had a vast impact and influence on the surrounding community. If this education is also synchronized with formal education, it will be able to strengthen and facilitate the understanding of the public towards the importance of religion.

\section{The Approach to Actualization of Multicultural Islamic Thought}

The approach to minority groups could be achieved to the greatest level by Kiai M. Sholeh Bahruddin and Kiai Abdullah Syam because both Kiai used several synergized approaches. In this case, Kiai Sholeh used moral, psychological, and theological approaches, whereas Kiai Abdullah Syam used religious, cultural, social, economic, and educational approaches. All approaches were directed to move centrally to reach its objectives.

In teaching about moderation, Kiai Sholeh emphasizes the actual practice in the form of words, actions, respecting the conditions and circumstances of other people, especially those with different beliefs. In addition, he has a high sense of empathy when asked for support in the establishment of houses of worship for minorities. Compared to Kiai Sholeh, Kiai Abdullah Syam has a slightly different approach, by which he places more emphasis on educational, social, and artistic aspects, which incidentally is one of the forms carried out by marginalized communities in terms of economy.

The approach taken is an interaction between Islamic relations and local culture to build harmony in social life. At least five forms of relationships exist, namely adaptation, 
accommodation, purification, rejection, and elimination. Adaptation means that the teachings in Islam are teachings that are always adapted to the conditions of society. Islam can adapt to people's lives in the form of activities, religion, society, arts and culture, and others. In addition, Islam is also regarded as accommodative teaching. This is perceived when the new local community has a limited ability to perform worship, especially those that are mandatory, then they are given leniency according to their previous abilities. This concept reflects that Islam accommodates the interests of the community according to their level of ability first, which portrays that society cannot be given a heavy obligation directly.

In terms of purification, rejection, and elimination, it is also an important aspect to be considered, in which Islamic scholars usually provide an understanding of the purification of their beliefs with Islamic teachings through symbols that are easy to understand. For example, people who want to embrace Islam are symbolized by entering a gate, in which the root word has the meaning of 'forgiveness' in Arabic. Likewise, in terms of rejection and elimination, Islam describes rejection and elimination in a polite and respectable way.

The moral approach used by Kiai M. Sholeh Bahruddin was displayed in the form of upright, polite, and friendly behavior so that he had a special affinity with many minority groups. This moral approach also contributed to harmonious practices of diversity in life. The psychological approach in the form of 'teposeliro' refers to the exploration of feelings in being a minority in the middle of the majority who need real attention and support, including the support in establishing places of worship such as churches. This approach contributes 
to creating calmness in plural society life. The theological approach is displayed by respecting the beliefs of each religion even when it is not in line with Islamic beliefs. This means that Islam is believed to be the truest religion conceptually, but when other people believe in different teachings, maintaining harmony is essential to respect each other. To respect does not mean to justify. Therefore, when there was a priest who wanted to convert to Islam, he was reminded by Kiai M. Sholeh Bahruddin to cancel his intention because it can disrupt the faith of his people. Regarding this, Kiai M. Sholeh Badarudin meant that the priest's desire to convert to Islam is principally the right of every individual. Nevertheless, in the context of religion, it will impact social life for the other groups, in which there will be a lot of friction in the community. There are concerns that it will become a social problem unless the person is no longer the main character and figure in religion. This theological approach contributes to the stability of the continuity of life with other religious communities to eliminate suspicions (Pengasuh Pesantren Ngalah Pasuruan, 2019).

The religious approach was implemented by Kiai Abdullah Syam by displaying the impression that Islam protects the adherents of other religions by its function as the mercy of rahmatan lil al-îalamîn. This approach eliminates the prejudice of the minority that the majority will crush the minority group. This is a contribution to building harmony in a plural society. Regarding this, the cultural approach was presented by creating a new culture in the form of art to attract the attention of a plural society. This approach contributed to the acculturation of the culture that develops in the community so that they feel that they belong together. 
The social approach is realized by prioritizing the relationship of all social, religious, and racial groups by assisting orphans and low-income families. This social approach contributes to egalitarianism and seeks to erode feudalism in society. Meanwhile, the economic approach is in the form of finding capital for people who need it and trying to improve their welfare. In comparison, the educational approach is shown by establishing educational institutions, teaching children, being involved in teaching in several educational institutions, and seeking education for the children of the poor. This approach eventually increases the knowledge of the community, especially marginalized communities (Syam, 2019).

Ideally, conflicts should no longer occur in religious doctrines because each religion teaches values about peace, compassion, brotherhood, equality, respect for belief, togetherness, human rights, mutual respect, and cooperation in solving problems together (Firdausi, 2013). Social approaches contributed to egalitarianism and attempted to erode feudalism in society (Baidhawy, 2007). The economic approach was portrayed in the form of finding capital for people in need to improve their welfare. In this regard, this approach contributed to improving the welfare of poor people (Baidhawy, 2012). At the same time, the educational approach was implemented by establishing educational institutions, teaching children, engaging in teaching in several educational institutions, and striving for the education of children who cannot afford it. This approach delivered the empowerment of communities, particularly marginal communities (Huda, 2015; Saini, 2018). 
When accompanied by supporting facilities, various approaches in understanding the culture of minority groups could achieve the maximum results. In relation to strengthening that approach, Kiai M. Sholeh Bahruddin supported the approach by giving the names of his education buildings with nationalist nuances such as the Nusantara Building, the NKRI Building, and Bhineka Tunggal Ika Middle School. There were many other facilities such as formal meetings with other religious leaders, informal (casual) meetings with them, visitation to their homes and followers, where communication and dialogue occurred. In addition, there were similarities between some aspects of tradition and religious traditions. For instance, the tradition of nyekar (cemetery visit) does not only belong to the tradition of Islamic boarding schools and Nahdlatul Ulama (NU) people but also to the minority groups, such as Christianity, Hinduism, and Buddhism, including the selametan tradition (Pengasuh Pesantren Ngalah Pasuruan, 2019). At the same time, the facilities provided by Kiai Abdullah Syam include Jagong Maton, cangkrukan, discussions, inspirational media, arts, and educational facilities. For example, Jagong Maton supports the success of Kiai Abdullah Syam in establishing and strengthening relations with both abangan and nonMuslim as a minority. Likewise, art is also utilized to unite and strengthen the relationship with abangan Muslims and non-Muslim minorities who had previously been interrupted in decades due to the exclusive religious thought and understanding (Syam, 2019).

Both Kiais who had approached the culture of minority groups have grown enormous psychological and strategic 
values. As a result, minority groups felt highly respected and cared for, thereby improving their peace from the possibility of a majority threat (Kistoro et al., 2020), especially the majority of Islam from the radical groups (Kanas et al., 2015). As a form of pleasure, they also gave greater attention back. In this case, they often visited and participated in the two Kiais' activities and provided material. They also used to give special gifts to Kiai M. Sholeh Bahruddin that could be used to help build the Islamic boarding schools. They, especially the adherents of Confucianism, donate several tons of rice and hundreds of millions of rupiah each year before the Eid, which is usually handed over to Kiai Abdullah Syam. Through this way, they perceive that they can contribute to the poor of the Muslim community. The donation was given to Kiai Abdullah Syam because the Community Islamic Boarding School caregiver was believed to be trustworthy so that their donations will be received by the targeted society.

The efforts to approach the minority culture could be maximized through the implementation of a socio-humanistic approach. The detailed forms of this approach were varied: Kiai M. Sholeh used a moral approach that was decomposed in the form of approaches to humanity, brotherhood, openness, and familiarity, whereas Kiai Abdullah Syam employed an artistic, cultural, social, and systematic approach. It turned out that the combination of these approaches was the most effective in achieving the maximum results in approaching the culture of minority groups. Regarding this, the point is to humanize humans (Beit-Hallahmi \& Argyle, 2014; Wentzer \& Mattingly, 2018; Winarto, 2014). 
The humanitarian approach could be reached through the expression of brotherhood, in which minority groups are regarded as siblings (Mubasirun, 2015). The openness approach was embodied in cultivating an open attitude to address any problem in the presence of minority groups. The familiarity approach was employed by establishing the relationship with minority groups as close as possible. The socio-cultural approach could be accomplished through artistic expression (displaying local art as an effort to strengthen relations with minority groups). Cultural, social expression (paying great attention to helping minority groups), and system expressions were implemented as an attempt to explore the intimacy with minority groups from various elements or components (Utami, 2015).

The approaches in the actualization of multicultural Islamic thought to create harmony in society taken by Kiai M. Sholeh Bahruddin and Kiai Abdullah Syam turned out to be not as straightforward as imagined. In this case, these approaches faced several challenges from the Muslim community itself (ranging from ordinary Muslim worshipers, ustadz, Islamic leaders, Kiais to Habibs). Consequently, the two Kiais tried to harmonize society at a large scale. Unfortunately, it was challenged by the internal Muslims themselves.

\section{E. The Channels of Actualization of Multicultural Islamic Thought in Response to Challenges in Building Community Harmonization}

The challenges to the attitude of Kiai M. Sholeh Bahruddin and Kiai Abdullah Syam when approaching the 
culture of minority groups were still within reasonable limits. The challenges arose because the actions of the two multiculturalist Kiais were seen as deviating from the Kiais' habits that they have witnessed in their daily lives. These challenges could be overcome by using several synergized channels. Kiai M. Sholeh Bahruddin used the argumentation channel in Jawab al-Mas'il's book, Senenan activities, and Manakiban activities. Senenan is a recitation that is routinely carried out on Mondays, which begins with reciting the holy verses of the Koran, followed by performing the Isha prayer in the congregation. After performing the Isha prayer led by Kiai Sholeh Bahrudin, the congregation performed the sunnah prayer of repentance, the daf'il balak prayer, the prayer of intent, and the prostration of gratitude. After that, scientific lectures were delivered to the congregation. This recitation is regarded as a medium for the community to gain knowledge and new insights about life for the community. While mankiban is a joint prayer activity carried out by reciting thayibah sentences contained in the Manaqib book by Sheikh Abdul Qadir Jailani.

Kiai M. Sholeh Bahruddin gave written answers in the book Jawab Al-Masil regarding the social and cultural relations with non-Muslims. He also explained the problem of social and cultural relations when doing the routine Senenan recitation and in Manakiban activities. All three activities were conducted to support each activity in response to the challenges of the social and cultural relations with nonMuslims (Pengasuh Pesantren Ngalah Pasuruan, 2019). Kiai Abdullah Syam employed Agustusan, culture, organizational development, silaturrahim, and networking channels. The 
Agustusan channel of activity was implemented by Kiai Abdullah Syam to explain his attitude in approaching the culture of minority groups (K. A. Syam, 2019). This moment is appropriate regarding the strengthening of the attitude of the Indonesian people to hold and practice of Bhineka Tunggal Ika (Lestari, 2015; Rahmawati et al., 2014). The cultural channel was utilized in channeling his thoughts about attitudes toward the culture of minorities in the presence of Muslims. Organizational development channels could be used in channeling answers about attitudes toward the culture of minority groups both directly by the two Kiais and through the management of the organization and also through the organization's activities. At the same time, silaturrahim channel was performed at the house of fellow Kiais, Islamic leaders, and Muslims. In this case, the two Kiais can explain their attitude towards the culture of minority groups. Network channels could be used to explain the attitude of the Kiais in approaching the culture of minority groups through efforts to build networks with various parties.

The challenges that arose from Muslims were eliminated by using social channels intensively. In this regard, social activities carried out intensively can easily arouse sympathy from the community, including people who challenge the two Kiais if the social activities were separated from the interests of practical politics and political flow because social activities carry very noble values, namely supporting, siding, defending, and fighting for the fate of the poor. The more they carry out social activities, the greater one's attention to the weak, needy, poor, orphans, widows, and many other disadvantaged groups (Bernhardt \& Singer, 2012). 
Social channels can also be reached by building relationships and interactions with as many people and groups as possible. This channel showed that both Kiai M. Sholeh Bahruddin and Kiai Abdullah Syam no longer draw the dividing line between human beings in terms of religion, culture, language, ethnicity, ethnicity, and other aspects in conducting community activities. Not surprisingly, the two Kiais who have multicultural Islamic thoughts also embrace non-Muslims, marginalized people, thugs, and officials, by which, in principle, they must do a good deed to everyone.

The channel of performing arts and culture could at least be utilized as a channel in responding to the challenges of Muslims, their leaders, and their Kiais in connection with the attitudes of Kiai M. Sholeh Bahruddin and Kiai Abdullah Syam, who had approached the culture of minority groups. At least through the performance of arts and culture, the two Kiais could show their challengers that the art and culture performers and their members were in the control of the two Kiais as opportunities to influence them even slower. This was far better than being controlled by disobedient people.

Challenges that arose regarding the attitude of the two Kiais in approaching the culture of minority groups could also be answered using the da'wah bi al-lisan (preaching orally) and da'wah bi al-hal (preaching by action). Preaching orally was performed to provide explanations, arguments, and answers to challenges related to the attitude of the Kiais approaching the culture of minority groups (Huda, 2016). Kiai M. Sholeh preached by giving mauidhah hasanah (good advice) in several studies, primarily through Manakiban activities. Likewise, Kiai Abdullah Syam delivered through both the 
lecture in the Islamic boarding school and his mosque and during the invitation to study in various regions and deliver lectures on the radio. However, for Kiai Abdullah Sham, the most important thing was da'wah bi al-hal (preaching through action). Preaching through action aims to show the concrete action of fighting for Muslims and the proof of the values in the lectures often voiced by the two Kiais from the stage so far. In another sense, preaching through action was a concrete result of the Kiais' preaching, which was always called upon orally on the stage (podium) (Sandi, 2017).

The challenges that arose from Muslims, their leaders, and/or their Kiais due to the attitudes of Kiai M. Sholeh Bahruddin and Kiai Abdullah Syam in approaching the culture of minority groups could be impeded by using social media routinely. The use of social media was very effective in building an impression or image (image building) (Juliswara, 2017). Regarding this, social media was used to voice the thoughts of the two Kiais in conveying certain aspects, including giving answers to various challenges that come from the Muslims themselves. More specifically, Kiai Sholeh used the Ngalah TV media and leaflets, which were usually distributed at activities held on Sundays and Mondays, whereas Kiai Abdullah Syam used social media websites, Facebook, Whatsapp groups, YouTube, and newspapers. These social media were fully optimized in conveying the ideas of both Kiais.

Furthermore, the challenges that arose from the Muslim community regarding the attitudes of Kiai M. Sholeh Bahruddin and Kiai Abdullah Syam in approaching the culture of minority groups could be tempered through the education channel. However, it requires quite a long time because 
there is no instant education (Muslih, 2016). Education is a strategic channel in instilling the Kiais' messages to students. Therefore, the education channel was never ignored by the two Kiais.

The implementation of the education channel is based on the emergence of multicultural education, which is defined as an educational model that seeks to build awareness of students to respect each other and respect cultural differences that develop in society (Miftah, 2016). The Indonesian nation is very diverse, so that multicultural education is very important to be internalized to students. In the context of Indonesian pluralism, religious education in schools should properly hold the principle of respecting the pluralistic beliefs of the community (Abdullah, 2005).

To support the education channel, the two Kiais also used the scientific meeting channel. This scientific meeting activity could be a suitable channel in answering various challenges, especially if the challengers like scientific activities. The scientific meeting held by Kiai M. Sholeh Bahruddin covered local, national, and international levels, whereas Kiai Abdullah Syam delivered scientific lectures on various campuses and had attended international scientific meetings. The scientific meetings conducted by the Kiais in response to various challenges support Raihani's statement that the discussion of multiculturalism has been intensified through seminars, conferences, talks through the media, and many others, even though Indonesia has not yet developed a multiculturalism model through which the government and society can implement (Raihani, 2014). 
One example of the answer to a challenge given in scientific activity is about the motive for holding this activity. So far, the congregational recitation, manakiban, and Senenan activities have reached about 5000 people from various regions. Most of them are from the underworld, in which the spirit underneath is more sincere and selfless. They flocked from various places, even from out of town, to take part in the event. This phenomenon, of course, rarely happens to mainstream people or elitists. Even if they are present, it is regarded as political motives. If it benefits their interests, they follow the activity, but they do not follow it if it does not benefit them.

All channels became media for the two Kiais during their involvement in various forums and community segments. The channels were synergized so that although they handled different fields, they still carried the same goal, namely building community harmony through efforts to actualize multicultural Islamic thought by approaching minority cultures, including channels that communicate answers to a variety of challenges originating from the internal Muslim circles.

The ideas and implementations that have been carried out by Kiai Sholeh Bahrudin and Kiai Abdullah Syam, on the one hand, become a breakthrough in religious education. Although still limited within the local scope, the evidence from the previous efforts and actions from both Kiais can be an essential reference to be applied at the national and even international levels.

Universal values are contained in the multiculturalism education that has been taught by Kiai Sholeh Bahrudin and Kiai Abdullah Syam. The calm value of religious tolerance, the 
value of togetherness regardless of ethnicity, religion, race, and the value of cooperation or mutual assistance are real examples of the teaching. Everything is not only happening in Indonesia, by which the international world is also experiencing the same thing.

Multicultural education is regarded as an important and crucially-needed education at this time. Regarding this, there is nothing wrong with taking positive values from what has been done by Kiai Shoeh Bahrudin and Kiai Abdullah Syam. The main concepts expressed and performed by the two Kiais are generally accepted everywhere, in which these were adjusted to the conditions and environment of each community.

The implications of this research in the context of national multiculturalism and global multiculturalism provide an expectation that the community, religious leaders, community leaders, and the governments are not resistant to diversity. The challenges ahead are increasingly complex and extraordinary. Through the actualization exemplified by religious leaders, people can have a broad influence to realize each other the importance of the main principles of multiculturalism, namely democracy, tolerance, and mutual respect.

\section{F. Conclusion}

The basis for the actualization of multicultural Islamic thought in building the community harmonization of Kiai M. Sholeh Bahruddin and Kiai Abdullah Syam includes respect for cultural and religious diversity, pluralist community life backgrounds, humanitarian motives in approaching the culture of minority groups, making Islam a guide to approaching the culture of minority groups by highlighting 
the similarities in each party. In other words, the actualization of multicultural Islamic thought should be based on social, humanistic, cultural, religious, and psychological grounds.

The actualization of multicultural Islamic thought in building community harmonization was realized through various synergized approaches, namely religious, moral, psychological, theological, cultural, social, and educational approaches. These approaches were accompanied by supporting facilities such as Jagong Maton, cangkrukan, discussions, media, arts, education, recitation, giving pluralist names to educational buildings, and meeting the leaders of other religions. Meanwhile, the most effective approaches include humanitarian, fraternal, openness, familiarity, arts, cultural, social, and systems approach.

The actualization of multicultural Islamic thought responds to various challenges in building harmonization through social channels, cultural arts, preaching, social media, silaturrahim, networking, education, and scientific meetings. Educational (in Ngalah Islamic Boarding School in the form of teaching, manakiban and Senenan activities, while in the AlAmin Community Islamic Boarding School is more in the form of formal education) and socio-cultural channels are regarded as the most effective channels. This means that a variety of channels can be used to answer the challenge of actualizing multicultural Islamic thought, and the most effective is the triangle channel (education, social, and cultural). 


\section{References}

'Âsyûr, I. M. At-T. (1984). At-tahrîr wa al- tanwir. Ad-Dar Tunisiyyah.

Abduh, M. T. (2014). Tata kelola pemerintahan negara madinah pada masa nabi Muhammad saw. In Right Jurnal Agama Dan Hak Azazi Manusia, 4(1), 13-30.

Abdullah, M. A. (2005). Pendidikan agama era multikultural multireligius (2005th Ed.). Psap.

Al-Asfahaniy, A.-A. Al-R. (2009). Mufradat al-fadzul qur'an. Darel Qalam.

Aly, A. (2015). Studi deskriptif tentang nilai-nilai multikultural dalam pendidikan di pondok pesantren modern Islam Assalaam. Jurnal Ilmiah Pesantren.

Amalia, T. Z. (2014). Multicultural education, the frame of learning Islamic studies towards Islamic religion teachers bilingually. Qijis (Qudus International Journal Of Islamic Studies), 1(1), 77-90. http://dx.doi. org/10.21043/qijis.v1i1.177

Amirin, T. M. (2013). Implementasi pendekatan pendidikan multikultural kontekstual berbasis kearifan lokal di Indonesia. Jurnal Pembangunan Pendidikan: Fondasi Dan Aplikasi. Https://Doi.Org/10.21831/Jppfa.V1i1.1047

Amsar A. Dulmanan. (2020). Multikulturalisme dan politik identitas: Catatan reflektif atas gagasan politik will kymlicka. Muqoddima: Jurnal Pemikiran Dan Riset Sosiologi, 1(1), 31-44. https://doi.org/10.47776/ MJPRS.001.01.03

Ansor, M. (2016). Post-Islamism and the remaking of Islamic public sphere in post-reform Indonesia. Studia Islamika, 23(3). Https://Doi.Org/10.15408/Sdi.V23i3.2412 
Azra, A. (2013). Jaringan ulama timur tengah dan kepulauan nusantara abad xvii \& xviii (1st Ed.). Kencana Prenadamedia Group.

Baharun, H., \& Awwaliyah, R. (2017). Pendidikan multikultural dalam menanggulangi narasi Islamisme di Indonesia. Jurnal Pendidikan Agama Islam (Journal of Islamic Education Studies). https://doi.org/10.15642/ Jpai.2017.5.2.224-243

Baidhawy, Z. (2007). Pemberdayaan mustad'afin melalui filantropi Islam. Shabran: Jurnal Studi Dan Dakwah Islam. http://hdl.handle.net/11617/1059

Baidhawy, Z. (2012). Distributive principles of economic justice: An Islamic perspective. Indonesian Journal of Islam And Muslim Societies. https://doi.org/10.18326/ Ijims.V2i2.241-266

Beit-Hallahmi, B., \& Argyle, M. (2014). The psychology of religious behaviour, belief, and experience. In The Psychology OfReligious Behaviour, Belief And Experience. https://doi.org/10.4324/9781315812601

Bernhardt, B. C., \& Singer, T. (2012). The neural basis of empathy. Annual Review of Neuroscience. https://doi. org/10.1146/Annurev-Neuro-062111-150536

Burhani, A. N. (2012). Al-tawassut wa-l i'tidāl: The NU and moderatism in Indonesian Islam. Asian Journal of Social Science.https://doi.org/10.1163/15685314-12341262

Cahyono, H. (2017). Pendidikan multikultural di pondok pesantren. At-Tajdid.

Dahlan, M. (2012). Paradigma usul fikih multikultural di Indonesia. Ijtihad: Jurnal Wacana Hukum Islam Dan Kemanusiaan. $\quad$ https://doi.org/10.18326/Ijtihad. V12i1.1-19 
Dasrun, H., Kuswarno, E., Zubair, F., \& Hafiar, H. (2017). Negosiasi citra budaya masyarakat multikultural. Jurnal Aspikom.

Fauzi, M. L. (2012). The roles of kyai and pesantren in preserving Islamic tradition and negotiating modernity. Journal of Indonesia Islam. 10.15642/】IIS.2012.6.1.125-144

Firdausi, M. A. (2013). Teologi universal: Solusi mencegah kekerasan berlatar agama. Ulul Albab Jurnal Studi Islam. https://doi.org/10.18860/Ua.V0i0.2321

Huda, Z. (2016). Dakwah Islam multikultural. Religia.

Ismail, F. (2012). Paving the way for interreligious dialogue, tolerance, and harmony: Following mukti ali's path. Al-Jami'ah: Journal of Islamic Studies. https://doi. org/10.14421/Ajis.2012.501.147-178

Juliswara, V. (2017). Mengembangkan model literasi media yang berkebhinnekaan dalam menganalisis informasi berita palsu (hoax) di media sosial. Jurnal Pemikiran Sosiologi. https://doi.org/10.22146/Jps.V4i2.28586

Kanas, A., Scheepers, P., \& Sterkens, C. (2015). Interreligious contact, perceived group threat, and perceived discrimination: Predicting negative attitudes among religious minorities and majorities in Indonesia. Social Psychology Quarterly. https://doi. org/10.1177/0190272514564790

Pengasuh Pesantren Ngalah Pasuruan, (2019).

Kistoro, H. C. A., Kartowagiran, B., Naim, N., Latipah, E., Putranta, H., \& Minggele, D. (2020). Islamophobia in education: Perceptions on the wear of veil/ niqab in higher education. Indonesian Journal OfIslam And Muslim Societies, 10(2), 227-246. https://doi.org/10.18326/ Ijims.V10i2.227-246 
Kunawi. (2012). Titik temu agama-agama dalam analisis interpretatif. Religio: Jurnal Studi Agama-Agama.

Kuswandi, I. (2014). Strategi pesantren dalam mencetak manusia Indonesia multi-kultur. Jurnal Pelopor Pendidikan.

Kymlicka, W. (2011). Multicultural citizenship within multination states. Ethnicities, 11(3), 281-302. https:// doi.org/10.1177/1468796811407813

Lestari, G. (2015). Bhinnekha Tunggal Ika: khasanah multikultural Indonesia di tengah kehidupan sara. Jurnal Pendidikan Pancasila Dan Kewarganegaraan. https://doi.org/Http://Dx.Doi.Org/10.17977/Jppkn. V28i1.5437

Lubis, M. A., Embi, M. A., Yunus, M. M., Wekke, I. S., \& Nordin, N. M. (2009). The application of multicultural education and applying ict on pesantren in South Sulawesi, Indonesia. Wseas Transactions On Information Science And Applications.

Madjid, N. (2003). Islam agama kemanusiaan, membangun tradisi dan visi baru Islam Indonesia (M. W. Nafis (Ed.); 2003rd Ed.). Paramadina.

Mailasari, D. U. (2016). Religiousness in a multicultural society: A study on roger williams' thought. Qijis (Qudus International Journal of Islamic Studies), 2(1), 1-25. http://dx.doi.org/10.21043/qijis.v2i1.1515

Miftah, M. (2016). Multicultural education in the diversity of national cultures. Qijis (Qudus International Journal Of Islamic Studies). https://doi.org/10.21043/Qijis. V4i2.1766

Mu'min, M., \& Mufid, F. (2018). The challenge of Islam nusantara against terrorism: Analysis study of Islam 
nusantara of ulama NU movement in Central Java. Addin. https://doi.org/10.21043/Addin.V12i1.4185

Huda, M. (2015). Hasan al-banna thought actualisation in the Islamic education development. Qudus International Journal Of Islamic Studies. http://dx.doi.org/10.21043/ qijis.v3i1.1602

Mubarak, M. Z. (2013). Dari semangat Islam menuju sikap radikal: Pemikiran dan perilaku keberagamaan mahasiswa UIN Syarif Hidayatullah Jakarta. Ma'arif, 8(1), 192-217.

Mubasirun, M. (2015). Persoalan dilematis muslim minoritas dan solusinya. Epistemé: Jurnal Pengembangan Ilmu Keislaman, 10(1). https://doi.org/10.21274/ Epis.2015.10.1.99-122

Muslih, M. (2016). Pendidikan Islam dalam konteks dakwah dan thalabul 'ilmi. At Ta'dib. https://doi.org/10.21111/ At-Tadib.V11i2.775

Noorhayati, S. M. (2017). Pendidikan multikultural di pesantren (Upaya membendung radikalisme di Indonesia). Madania: Jurnal Kajian Keislaman. https:// doi.org/10.29300/Madania.V21i1.212

Pranowo, M. B. (2009). Memahami Islam jawa (A. F. Kurniawan (Ed.); 1st Ed.). Alvabet.

Putranto, H. (2016). Ideologi pancasila berbasis multikulturalisme, sebuah pengantar (1st Ed.). Mitra Wacana.

Rahmawati. Yeni; Yi-Fong, Pai; Chen, H. (2014). The necessity of multicultural education in Indonesia. International Journal Of Education And Research. https: //www.ijern. com/journal/2014/October-2014/25.pdf 
Raihani. (2014). Creating multicultural citizens a portrayal of contemporary Indonesian education (1st Ed.). Routledge.

Rif 'Atul, M., Madrasah, T., Negeri, K., \& Jombang, I. (2015). Multikulturalisme pesantren di antara pendidikan tradisional dan modern. Jurnal Studi Islam.

Rosidi. (2017). Dakwah multikultural di Indonesia studi pemikiran dan gerakan dakwah abdurrahman wahid. Analisis: Jurnal Studi Keislaman. https: //doi. org/10.42042/Analisis.V13i2.708

Saifulah, S. (2014). Dakwah multikultural pesantren ngalah dalam meredam radikalisme agama. Islamica: Jurnal Studi Keislaman. https://doi.org/10.15642/ Islamica.2014.8.2.421-446

Saldana, M. J., Huberman, A. M., Miles, M. B. (2013). Qualitative Data Analysis: A Methods Sourcebook. Amerika Serikat: SAGE Publications.

Saini, P. (2018). Education and women empowerment in India. Journal Of Advances And Scholarly Researches In Allied Education. https://doi.org/10.29070/15/57678

Sandi, F. A. (2017). Dakwah bil-hal: Muhammadiyah strategy in the empowerment of disabilities groups in Yogyakarta. Ijasos- International E-Journal of Advances In Social Sciences. https://doi.org/10.18769/Ijasos.367315

Sulalah. (2012). Pendidikan multikultural, didaktika nilai-nilai universalitas kebangsaan (1st Ed.). UIN Maliki Press.

Syam, K. A. (2019). Pengasuh pesantren rakyat al-amin sumberpucung malang.

Syam, M. B. (2015). Kebijakan dan prinsip prinsip kenegaraan nabi Muhammad saw di madinah 622-632 M (Tinjauan perpektif pemikiran politik Islam). Kritis Jurnal Sosial Ilmu 
Politik Universitas Hasanuddin, 1(1), 157-174. https:// journal.unhas.ac.id/index.php/kritis/article/view/10

Tanudirjo, D. A. (2011). Membangun pemahaman multikulturalisme : perspektif arkeologi.

Umar, A. R. M. (2016). A genealogy of moderate Islam: governmentality and discourses of islam in Indonesia's foreign policy. Studia Islamika. https://doi. org/10.15408/Sdi.V23i3.3157

Utami, L. S. S. (2015). Teori-teori adaptasi antar budaya. Jurnal Komunikasi.

Wakano, A. (2019). Nilai-nilai pendidikan multikultural dalam kearifan lokal masyarakat Maluku. Al-Iltizam: Jurnal Pendidikan Agama Islam. https://doi.org/10.33477/ Alt.V4i2.1006

Wentzer, T. S., \& Mattingly, C. (2018). Toward a new humanism: An approach from philosophical anthropology. Hau: Journal of Ethnographic Theory. https://doi. org/10.1086/698361

Widiastuti, A. S. Dan W. (2018). Multicultural education model in traditional pesantren in Tasikmalaya to prevent the threat of radicalism. Ilmu-IImu Sosial Dan Humaniora.

Winarto, Y. T. (2014). 'Memanusiakan manusia' dalam lingkungan yang tangguh: Mengapa 'jauh panggang dari api'? Antropologi Indonesia. https://doi.org/10.7454/ Ai.V34i1.3198

Yakin, A. U. (2016). Islam moderat dan isu-isu kontemporer: demokrasi, pluralisme, kebebasan beragama, non-muslim, poligami, dan jihad (1st Ed.). Kencana Prenadamedia Group. 
Yunanto, S., \& Hamid, A. F. A. (2013). Fragmentation and conflict among Islamic political parties in Indonesia during reformasi era (1998-2009): Anatomy, factors, and implications. Journal of Indonesian Islam. https:// doi.org/10.15642/Jiis.2013.7.2.337-365

Misrawi, Z. (2012). Kesadaran multikultural dan deradikalisasi pendidikan Islam: Pengalaman bhinneka tunggal ika dan qabul al-akha. Jurnal Pendidikan Islam. http:// ejournal.uin-suka.ac.id/tarbiyah/index.php/JPI/ article/view/1134/1030 